\title{
СТУДИЈСКИ ПРОГРАМИ ОСНОВНИХ АКАДЕМСКИХ СТУДИЈА ПЕДАГОГИЈЕ НА ФИЛОЗОФСКОМ ФАКУЛТЕТУ У НИШУ ОД 2000. ДО 2021. ГОДИНЕ
}

\author{
Марина Матејевић ${ }^{3}$, Марија Ђорђевић \\ Универзитет у Нишу, Филозофски факултет, Департман за педагогију
}

\begin{abstract}
Ancmpaкm: У раду је анализирано шест студијских програма Департмана за педагогију од његовог оснивања до ове, 2021. године. Коришћена је техника анализе садржаја доступних програмских докумената. Основне јединице анализе биле су: студијски програм (у оквиру њега: предмети, изборност, акредитација, ЕСПБ, стручна пракса), сврха, циљ и исходи програма. Резултати анализе показују недвосмислен напредак у развоју програма од оснивања Департмана до данас. У сваком новом програму додавали су се нови предмети у складу са потребама и развојем система васпитања и друштвене заједнице, што је било условљено и присуством адекватнијих потенцијала на Департману за педагогију. У програмима је све више изборних модула и предмета, а стручна пракса је заступљена на све адекватнији начин. Континуиране допуне циљева и исхода, и креирање нових предмета, резултат су сталног критичког преиспитивања актуелног програма, многобројних анализа и израз тежњи да се достигне највиши ниво квалитета студијског програма и компетенција дипломираних студената педагогије. Наравно, увек ће постојати простор у коме се сваки студијски програм може даље унапређивати и мењати у складу са динамичним друштвом у коме живимо.
\end{abstract}

Кључне речи: Департман за педагогију, ОАС, педагогија, студијски програм

\section{Увод}

Департман за педагогију основан је 27.12.1999. године као Студијска група за педагогију, одлуком Управног одбора Филозофског факултета Уни-

\footnotetext{
${ }^{1}$ Рад је настао као резултат истраживања у оквиру пројекта: „Развој и перспективе Департмана за педагогију Филозофског факултета у Нишу“, бр. 100/1-10-5-01, финансираног од стране Филозофског факултета Универзитета у Нишу.

${ }^{2}$ Ово истраживање подржало је Министарство просвете, науке и технолошког развоја Републике Србије (Уговор бр. 451-03-9/2021-14/200165).

${ }^{3}$ marina.matejevic@filfak.ni.ac.rs
} 
верзитета у Нишу. Влада Републике Србије дала је своју сагласност за њено оснивање 16.03.2000. године. Наставно-научно веће Филозофског факултета у Нишу усвојило је први наставни план студија педагогије. 19. јуна 2000. године, први студенти уписани су у школској 2000/2001. години. Од оснивања Департмана за педагогију па до 2021. године усвојено је шест студијских програма. Као што смо већ поменули, први 2000. године, затим следећи, 2004. године, потом, 2006. године, а затим 2008. године први акредитовани програм у оквиру Болоњске реформе високог образовања, следећи студијски програм је акредитован 2014. године, и ове 2021. године успешно је акредитован најновији студијски програм на Департману за педагогију.

\section{Студијски прогами основних академских студија: 2000-2021.}

У првом студијском програму на Студијској групи за педагогију из 2000. године, били су присутни двосеместрални предмети, и чак један четворосеместрални предмет, Општа педагогија. Изборни предмети су били предвиђени само на трећој и четвртој години студија, и такође су били двосеместрални. Стручна пракса се реализовала на трећој и четвртој години, две недеље у предшколској установи и две недеље у школи. У студијском програму је било укупно 24 предмета, заједно са изборним подручјем, од чега су обавезни премети били: Увод у педагогију, Општа педагогија, Историја педагогије, Андрагогија, Предшколска педагогија, Методологија педагошких истраживања, Статистика у педагогији, Дидактика, Савремени педагошки правци и системи, Школска педагогија, Методика наставе српског језика, Методика наставе математике, Методика наставе природе и друштва, Општа психологија са психологијом личности, Увод у филозофију, Логика са општом методологијом, Социологија, Развојна психологија, Етика, Социологија васпитања и образовања, Педагошка психологија, и страни језик. Разлог за присуство великог броја психолошких, социолошких и филозофских дисциплина лежи вероватно у томе да је у овом периоду било недовољно наставника и сарадника на Департману за педагогију и подршка са других департмана била је драгоцена за почетак рада Департмана за педагогију. Оно што је у овом програму занимљиво је такође то да су предмети са других студијских програма били у категорији обавезних предмета, док су у категорији изборних предмета биле педагошке и методичке дисциплине, у оквиру изборног предмета 1: Породична педагогија, Педагогија слободног времена и Домска педагогија, а у оквиру изборног предмета 2: Методика рада школског педагога, Методика уметничког образовања, или Методика физичког васпитања, Методе рада са даровитом децом, Методе рада са децом ометеном у развоју, Методе образовања за масовно комуницирање, Методе образовања за развој и толеранцију. Веома је необично да методике наставе буду у категорији обавезних предмета, а да методика рада школског педагога буде у категорији изборног предмета. Ово се вероватно може тумачити остатком тенденције да 
се педагози припремају за професоре педагогије у учитељским школама, а потом у педагошким академијама, али с обзиром да је још 1990. године образовање учитеља подигнуто на факултетски ниво, заиста зачуђује ова инертност и оријентисаност студијског програма ка неким прошлим временима. Такође је занимљива и чињеница да је Породична педагогија у категорији изборних предмета, иако је социјализам као друштвено уређење укинут још 1990. године, тенденција маргинализације породичног васпитања, која је била део социјалистичког васпитања, и даље била присутна у овом студијском програму педагогије. Због свих ових слабости и недостатака сачињен је нови студијски програм, који је усвојен 2004. године.

Студијски програм основних студија из 2004. године, се према својој структури разликује од претходног, у односу на број изборних блокова, односно предмета који почињу од прве године, као и према другачијој заступљености педагошких дисциплина. Уместо искључиво двосеместралних предмета, заступљени су једносеместрални предмети у оквиру изборних предмета, такође је и Општа педагогија као четворосеместрални предмет, подељена на два двосеместрална предмета, на Општу педагогију и Теорију васпитања. Тенденција увођења изборних предмета је у овом наставном плану била изражена и у односу на концепт изборних модула, којих је било укупно шест, а студенти су били у обавези да бирају на четвртој години два модула. У наставном плану су били заступљени следећи модули: Модул 1. Предшколска педагогија, са предметима: Методика рада предшколског педагога, Системи и програми предшколског васпитања, Развој говора и стваралаштва предшколске деце; Модул 2. Школска педагогија, са предметима: Методика рада школског педагога, Методика разредне наставе, и Грађанско васпитање; Модул 3. Образовање одраслих, са предметима: Андрагошка дидактика, Компаративна андрагогија, Андрагогија рада; Модул 4. Ваншколска педагогија, са предметима: Методика рада у установама социјалне заштите, Саветодавни рад, и Васпитна функција медија; Модул 5. Теоријско методолошки приступи и оријентације у педагогији, са предметима: Истраживачке оријентације (парадигме) и приступи у педагогији, Савремене концепције васпитања, Примењена истраживања у области васпитања и образовања, и Модул 6. Образовна политика, са предметима: Економика образовања, Управљање у образовању, Администрација у образовању. У оквиру обавезних предмета заступљене су следеће дисциплине: Увод у педагогију, Историја педагогије, Општа педагогија, Методологија педагогије, Теорија васпитања, Статистика, Дидактика, Предшколска педагогија, Школска педагогија, Породична педагогија, Андрагогија, Мултимедијални системи у образовању, Општа психологија са психологијом личности, Развојна психологија, Увод у социологију, Социологија васпитања и образовања, Педагошка психологија, и Страни језик. У првој години су у оквиру изборног предмета 1 и 2 понуђени следећи предмети: Увод у филозофију, Етика, Логика, и Теорија сазнања; на другој години у оквиру изборног предмета 3 и 4 понуђени су следећи предмети: Ментална хигијена, Психопатологија деце и омладине, Комуникација у васпитању, и Аксиологија; на трећој години у оквиру изборних предмета 5 и 
6 понуђени су следећи предмети: Примена теорије учења на област наставе и васпитања, Теорија курикулума, Евалуација, и Социјална психологија.

Може се констатовати да су промене у овом студијском програму биле у складу са тенденцијама у савременом образовању и целовитијем сагледавању улоге педагога у различитим образовним институцијама, као и у установама социјалне заштите. Значајан недостатак овог наставног плана јесте свакако недовољно праксе која је била заступљена само у седмом семестру, што заиста не омогућава адекватну практичну оспособљеност будућих педагога. Такође треба констатовати да су велике могућности избора у оквиру модула биле у суштини веома скромне, јер није постојала адекватна кадровска подршка на Департману за реализацију свих модула, већ само предшколског и школског, али је свакако значајна визија коју су наставници и сарадници на Департману имали у сагледавању улоге педагога у различитим сегментима васпитно-образоване делатности.

Нови студијски програм усвојен је већ 2006. године, тенденција је била да се полако започне припрема за прихватање Болоњског процеса, јер су у овом наставном плану присутни, ЕСПБ бодови, односно кредити, који је требало да укажу на оптерећење студената при реализовању наставних садржаја. Прихваћен је критеријум да оптерећење студената треба да буде 30 ЕСПБ по семестру, односно 60 ЕСПБ у школској години, при чему, по завршетку студија, студент стиче 240 ЕСПБ. Сви наставни предмети у категорији и обавезних и изборних предмета су једносеместрални и сваки премет носи 5 ЕСПБ. У категорији обавезних предмета налазе се следећи предмети: Увод у педагогију, Историја педагогије I, Општа психологија, Теорије когнитивног развоја, Увод у социологију, Основи педагогије, Историја педагогије II, Психологија личности, Социоафективни развој детета, Страни језик, Општа педагогија, Методологија педагогије, Теорије интелектуалног васпитања, Социологија васпитања и образовања, Педагошка психологија, Мултимедијални системи у образовању, Истраживања у педагогији, Теорије моралног васпитања, Образовање и социјална селекција, Педагошка статистика, Дидактика I, Предшколска педагогија, Школска педагогија, Андрагогија, Детињство, култура и васпитање, Дидактика II, Програми предшколског васпитања, Систем васпитања и образовања, Социологија наставника, Породична педагогија, Савремени педагошки правци, Образовна технологија, Методика рада школског педагога, Породица и васпитно-образовне установе, Методика рада педагога у предшколским установама, Педагошка комуникација, Методика васпитно-образовног рада, Педагошка превенција поремећаја у понашању. Изборни предмети су присутни у сваком семестру, значи осам изборних позиција у оквиру којих се нуде по два предмета: Увод у филозофију, Теорија сазнања, Логика, Етика, Ментална хигијена, Педагошка информатика, Увод у академско писање, Психопатологија деце и омладине, Рад са децом са посебним потребама, Теорија курикулума, Филозофија васпитања, Образовање за треће доба, Основи социјалне педагогије, Андрагошка дидактика, Социјална психологија и Мултимедијална дидактика. Изборни предмети су из различитих области, филозофије, психологије, 
социологије и педагогије, што омогућава студентима да захваљујући изборним предметима профилишу своје студије. Такође треба поменути да је стручна пракса присутна само у четвртој години студија, обавља се из следећих предмета: Предшколска педагогија 15 часова, Методика рада школског педагога 30 часова, Породична педагогија 15 часова, што указује на неадекватно присуство стручне праксе у овом наставном плану. Ипак треба констатовати да постоји отвореност ка иновацијама и жеља да се ухвати корак са Болоњском реформом високог образовања, али због недостатка довољног броја наставника и сарадника на Департману изборне позиције нису постављене са могућностима избора у оквиру већег броја предмета, што би створило адекватније могућности избора и профилисања студија. Понуђени предмети у изборним позицијама указују такође и на оријентацију Департмана да у наставном плану буду садржаји који су у складу са потребама образовног система, Педагошка информатика, која иде у сусрет дигиталним компетенцијама наставника, што је императив савременог образовања. Такође треба поменути и процес инклузије, који је у овом периоду такође био веома актуелан, а изборни предмет Рад за децом са посебним потребама, такође указује на тенденцију наставника на Департману да ослушкују потребе савремене школе и да на адекватан начин уводе савремене и значајне садржаје, како би на што адекватнији начин подстакли професионални развој будућих педагога.

Законом о високом образовању из 2005. године (Службени гласник РС, 2005. бр. 76.) предвиђена је акредитација студијских програма, тако да је нови студијски програм акредитован 2008. године и то је био први студијски програм који је акредитован према стандардима који су били дефинисани у оквиру Болоњске реформе високог образовања. С обзиром да је на Департману била присутна тенденција приликом усвајања претходног наставног плана, да се испоштују неки од стандарда Болоњског процеса, у овом наставном плану није било превише новина. Разлика је била присутна у оквиру ЕСПБ бодова, сви предмети нису више имали 5 ЕСПБ као у претходном плану, стога ћемо поред обавезних и изборних предмета навести и број ЕСПБ бодова. У оквиру обавезних предмета присутни су следећи предмети: Увод у педагогију, 5 ЕСПБ, Историја педагогије I, 5ЕСПБ, Општа психологија, 5 ЕСПБ, Теорије когнитивног развоја, 4 ЕСПБ, Основи социологије, 5 ЕСПБ, Основи педагогије, 5 ЕСПБ, Историја педагогије II, 5 ЕСПБ, Психологија личности, 5 ЕСПБ, Теорије емоционалног развоја, 4 ЕСПБ, Општа педагогија, 5 ЕСПБ, Методологија педагогије, 5 ЕСПБ, Теорије интелектуалног васпитања, 5 ЕСПБ, Социологија васпитања и образовања, 5 ЕСПБ, Педагошка психологија, 5 ЕСПБ, Мултимедијални системи у образовању, 6 ЕСПБ, Истраживања у педагогији, 6 ЕСПБ, Теорије моралног васпитања, 5 ЕСПБ, Образовање и социјална селекција, 5 ЕСПБ, Педагошка статистика, 4 ЕСПБ, Дидактика I, 7 ЕСПБ, Предшколска педагогија, 6 ЕСПБ, Школска педагогија, 6 ЕСПБ, Андрагогија, 7 ЕСПБ, Детињство, култура и васпитање, 5 ЕСПБ, Дидактика II, 7 ЕСПБ, Програми предшколског васпитања, 5 ЕСПБ, Школски систем, 6 ЕСПБ, Социологија наставника, 5 ЕСПБ, Породична педагогија, 7 ЕСПБ, Савремени педагошки правци, 5 ЕСПБ, 
Образовна технологија, 6 ЕСПБ, Методика рада школског педагога, 7 ЕСПБ, Педагогија родитељства, 6 ЕСПБ, Методика рада педагога у предшколским установама, 7 ЕСПБ. У изборном подручју су и у овом наставном плану присутна по два предмета у сваком семестру, с тим што су у првом семестру присутне две изборне позиције: Страни језик, 6 ЕСПБ, и изборна позиција II Увод у филозофију 5 ЕСПБ и Увод у професију 5 ЕСПБ, а у другом семестру само Страни језик 6 ЕСПБ. На осталим годинама понуђени су следећи предмети: Етика и информатика, по 5 ЕСПБ, Ментална хигијена и Компјутерски програми за обраду података по 5 ЕСПБ, Развој говора и стваралаштва предшколске деце и Теорија курикулума по 5 ЕСПБ, Социјална педагогија, и Рад са децом са посебном друштвеном подршком, по 5 ЕСПБ, Педагошка превенција поремећаја у понашању и Настава грађанског васпитања по 5 ЕСПБ, Социологија омладине и Образовање за треће доба по 6 ЕСПБ. Стручна пракса обавља се на четвртој години из следећих предмета: Методика рада школског педагога 30 часова, Педагогија родитељства 15 часова, и Методика рада у предшколским установама 30 часова, и реализује се у предшколским установама, основним и средњим школама и установама социјалне заштите. Може се констатовати да је у овом наставном плану повећан број часова за стручну праксу, у односу на претходни наставни план, али се такође може констатовати и неадекватна заступљеност стручне праксе, само на четвртој години студија.

Сврха студијског програма, дефинисана стандардом, била је да образује студенте за радно место сарадника у предшколским установама, основним и средњим школама, установама социјалне и здравствене заштите, установама у области културе и другим службама јавног сектора и невладиним организацијама. Студенти који су завршили основне академске студије педагогије требало би да буду оспособљени за истраживање проблема образовања и васпитања на свим нивоима и узрастима, свестрано анализирање и процењивање ефеката примењиваних поступака, облика и метода, за сагледавање њихових позитивних страна и недостатака, као и за учествовање у планирању и анализи развоја образовања и његовој подршци. Циљ основних студија педагогије био је пружање репрезентативних увида у актуална кретања у савременој теорији и пракси свих дисциплина релевантних за разумевање проблематике којом се баве педагози, како би студенти педагогије били оспособљени за: овладавање појмовима и основним чињеницама, принципима и законитостима у васпитно-образовном раду; свестрано анализирање и процењивање ефеката примењиваних поступака, облика и метода, уведених иновација, за сагледавање њихових позитивних страна и недостатака; успешан самосталан практичан рад у свим врстама образовних установа у својству школског/предшколског педагога; самостално и компетентно истраживање проблема образовања и васпитања на свим нивоима и узрастима; учествовање у планирању и анализи развоја образовања и његовој подршци. Савладавањем студијског програма студент би стекао следеће опште и предметно-специфичне компетенције: сагледавање теоријских и практичних импликација различитих система и школа у педагошком раду у различитим васпитно-образовним институцијама; разу- 
мевање принципа и законитости васпитно-образовног процеса; учествовање у тимском раду и другим кооперативним облицима рада; критичко промишљање релевантних проблема у васпитању и образовању; развијање квалитетне интеракције између учесника васпитно-образовног процеса; прецизно конципирање налаза својих и других истраживања и компетентно презентовање; укључивање у процес континуираног образовања; показивање сензибилности за етичке проблеме; учествовање у стручним дискусијама које се тичу унапређивања струке; креативно и стваралачко трагање за решењима у васпитној стварности. Када је реч о исходима учења, по завршетку основних студија очекивало се да студент буде у стању да: разуме сложеност образовне установе као дела система васпитања, да разуме врсте улога, сложеност и међузависност социјалних интеракција у њој; уме да даје квалификоване предлоге за побољшање рада наставника и других актера у школи/предшколској установи, на начин који је прихватљив за њих; уме да идентификује проблеме чије решавање превазилази његове професионалне компетенције и да буде у стању да упути на одговарајуће институције или професионалце; уме компетентно да прати, евалуира и унапређује сопствени рад и ради на сопственом професионалном усавршавању узимајући у обзир најновија научна и стручна достигнућа.

Следећи студијски програм акредитован је 2014. године, према овом наставном плану се образују педагози данас, с тим што ће следећа генерација педагога, у школској 2021/22. години бити уписана по новом наставном плану. И овде бисмо могли да констатујемо да разлике нису велике у односу на претходни наставни план. У оквиру обавезних предмета присутни су следећи предмети: Увод у педагогију, 6 ЕСПБ, Историја педагогије I, 5ЕСПБ, Општа психологија, 5 ЕСПБ, Теорије когнитивног развоја, 5 ЕСПБ, Основи социологије, 5 ЕСПБ, Основи педагогије, 6 ЕСПБ, Историја педагогије II, 5 ЕСПБ, Психологија личности, 5 ЕСПБ, Теорије емоционалног развоја, 5 ЕСПБ, Општа педагогија, 6 ЕСПБ, Методологија педагогије, 5 ЕСПБ, Теорије интелектуалног васпитања, 5 ЕСПБ, Социологија васпитања и образовања, 5 ЕСПБ, Педагошка психологија, 5 ЕСПБ, Мултимедијални системи у образовању, 5 ЕСПБ, Српски језик, 4 ЕСПБ, Истраживања у педагогији, 5 ЕСПБ, Теорије моралног васпитања, 5 ЕСПБ, Образовање и социјална селекција, 5 ЕСПБ, Статистика у педагошким истраживањима, 5 ЕСПБ, Дидактика I, 6 ЕСПБ, Предшколска педагогија, 5 ЕСПБ, Школска педагогија, 5 ЕСПБ, Андрагогија, 5 ЕСПБ, Детињство, култура и васпитање, 5 ЕСПБ, Дидактика II, 6 ЕСПБ, Програми предшколског васпитања, 5 ЕСПБ, Школски систем, 5 ЕСПБ, Социологија наставника, 5 ЕСПБ, Породична педагогија, 6 ЕСПБ, Савремени педагошки правци, 5 ЕСПБ, Образовна технологија, 5 ЕСПБ, Методика рада школског педагога, 5 ЕСПБ, Педагогија родитељства, 5 ЕСПБ, Методика рада педагога у предшколским установама, 5 ЕСПБ. У изборном подручју су и у овом наставном плану присутна по два изборна предмета у сваком семестру, с тим што су у првом семестру присутне две изборне позиције: Страни језик, 4 ЕСПБ, и изборна позиција II - Филозофија васпитања и образовања 5 ЕСПБ и Увод у професију педагога 5 ЕСПБ, а у другом семестру само Страни језик 4 ЕСПБ. На осталим годинама 
понуђени су следећи предмети: Етика и информатика, по 4 ЕСПБ, Заштита менталног здравља и Педагошко академско писање по 5 ЕСПБ, Развој говора и стваралаштва предшколске деце и Докимологија по 5 ЕСПБ, Основи социјалне педагогије, и Рад са децом са потребом за посебном друштвеном подршком, по 5 ЕСПБ, Социологија наставника и Методика наставе грађанског васпитања по 5 ЕСПБ. У четвртој години су такође у VIII семестру присутне две изборне позиције: Социологија омладине и Интеркултурално васпитање по 4 ЕСПБ, и Образовање за треће доба и Педагошка превенција поремећаја у понашању по 4 ЕСПБ. Када је реч о стручној пракси, онда свакако треба констатовати да је присутна стручна пракса 1 на трећој години, из области школске, предшколске и породичне педагогије са по 20 часова и дидактике са 15 часова, укупно 75 часова, и реализује се у предшколским установама, основним и средњим школама и установама социјалне заштите. На четвртој години присутна је стручна пракса 2 из Методике рада школског педагога, и Методике рада предшколског педагога са по 20 часова, и реализује се у предшколским установама, основним и средњим школама. Овај наставни план је веома сличан претходном, што се тиче обавезних и изборних предмета, највећа разлика у односу на претходни је повећан број часова стручне праксе у трећој и четвртој години, што је и те како значајно за професионалне компетенције студената педагогије.

Сврха студијског програма аредитованог 2014. је у стандардима експлицитније дефинисана, па се, поред образовања за радно место сарадника у разним установама, истиче и да ОАС педагогије пружају могућност стицања и ојачавања друштвено оправданих и професионално корисних компетенција за: свестрано анализирање и процењивање ефеката примењиваних поступака, облика и метода; сагледавање њихових позитивних страна и недостатака; партиципирање у планирању и анализи развоја образовања и његовој подршци; практичан рад и стваралаштво у свом домену; теоријско и практично истраживање проблема образовања и васпитања на свим нивоима и узрастима. Сврха студија је усмерена и на развој способности проналажења решења, социјалних и комуникативних компетенција, организационих вештина, способности евалуације, способности деловања у заједници, вештина личног професионалног развоја и унапређивања професије, као и способности које произилазе из професионалне праксе (методичке компетенције, познавање етичких и моралних норми професије, саморазумевање, интеркултуралност и мултикултуралност). Циљ студија је остао исти, мада је богатије конципиран. Осим неких основних очекиваних исхода, списку је додат и део везан за практичан и истраживачки рад: да осмисли, испланира, процени, измери параметре неопходне за реализацију самосталаног практичног рада у свим врстама образовних установа (предшколске установе, основне и средње школе, специјалне школе, установе за образовање одраслих, посебно профилисане образовне институције) у својству школског/предшколског педагога, односно да креативно и стваралачки трага за решењима у васпитној стварности; прецизно конципира, анализира и упоређује налазе својих и других истраживања, компетентно их демонстрира и активно примењује у свом раду. Исходи студијског програма проширени су у 
стандарду и подељени посебно на опште, посебно на предметно-специфичне. Савладавањем студијског програма студент стиче следеће опште способности: поред поменутих (у претходној акредитацији) способности познавања и разумевања принципа и законитости васпитно-образовног процеса; учествовања у тимском раду и другим кооперативним облицима рада; критичког промишљања релевантних проблема у васпитању и образовању; подстицања, развијања и унапређивања квалитетне интеракције између учесника васпитно-образовног процеса; учествовања у стручним дискусијама које се тичу унапређивања струке; прецизно конципирање налаза својих и других истраживања и компетентног презентовања утврђених резултата; овде се додају и способности: разумевања, анализирања, примене и евалуације најзначајнијих педагошких сазнања и идеја; показивања сензибилности за етичке и интеркултуралне проблеме; активног и одговорног односа према сопственом професионалном развоју у смислу укључивања у процес континуираног образовања и самообразовања. Савладавањем студијског програма студент стиче следеће предметно-специфичне способности: темељног познавања и разумевања основних поставки педагошких дисциплина; разумевања сложености образовне установе као дела система васпитања, врста улога, комплексност и међузависност социјалних интеракција у њој; креирања квалификованих предлога за побољшање рада наставника и других актера васпитно-образовних процеса; идентификовања проблема чије решавање превазилази његове професионалне компетенције и упућивање на одговарајуће институције или професионалце; праћења, евалуације и унапређивања сопственог рада и професионално усавршавање у складу са најновијим научним и стручним достигнућима; примене стечених знања у непосредној васпитно-образовној пракси и решавања конкретних проблема употребом релевантних педагошко-дидактичко-методичких поступака; креативног и стваралачког трагања за иновацијама и њихова непосредна примена у педагошкој стварности употребом савремених информационих технологија; интердисциплинарног приступања проблемима васпитања и образовања.

Најновији студијски програм, успешно је акредитован ове, 2021. године, и школске 2021/2022. године биће уписана прва генерација која ће студирати по овом програму. У најновијем наставном плану присутни су нови предмети, што указује на присуство адекватнијих потенцијала за развој Департмана и студијског програма. У оквиру обавезних предмета присутни су следећи предмети: Увод у педагогију, 6 ЕСПБ, Историја педагогије I, 5 ЕСПБ, Општа психологија, 5 ЕСПБ, Основи социологије, 5 ЕСПБ, Основи педагогије, 6 ЕСПБ, Историја педагогије II, 5 ЕСПБ, Развојна психологија детињства, 5 ЕСПБ, Педагошка информатика, 5 ЕСПБ, Социологија васпитања и образовања, 5 ЕСПБ, Општа педагогија, 6 ЕСПБ, Методологија педагогије, 5 ЕСПБ, Теорије интелектуалног васпитања, 5 ЕСПБ, Емоционално васпитање, 4 ЕСПБ, Педагошка психологија, 5 ЕСПБ, Детињство, култура и васпитање, 5 ЕСПБ, Истраживања у педагогији, 5 ЕСПБ, Теорије моралног васпитања, 5 ЕСПБ, Статистика у педагошким истраживањима, 4 ЕСПБ, Дидактика I, 6 ЕСПБ, Предшколска педагогија, 5 ЕСПБ, Школска педагогија I, 5 ЕСПБ, Мултимедијални системи у 
образовању, 5 ЕСПБ, Педеутологија, 4 ЕСПБ, Дидактика II, 6 ЕСПБ, Програми предшколског васпитања, 5 ЕСПБ, Школска педагогија II, 5 ЕСПБ, Породична педагогија, 6 ЕСПБ, Савремени педагошки правци, 5 ЕСПБ, Методика васпитно-образовног рада, 6 ЕСПБ, Методика рада школског педагога, 6 ЕСПБ, Педагогија родитељства, 5 ЕСПБ, Методика рада педагога у предшколским установама, 6 ЕСПБ, Андрагогија 6 ЕСПБ, Образовна технологија, 5 ЕСПБ, Школски систем. 5 ЕСПБ.

У изборном подручју су и у овом наставном плану присутни изборни блокови, укупно 11 изборних блокова. Изборни блок 1 (4 ЕСПБ): Енглески језик, Француски језик и Немачки језик, и Изборни блок 2 (5 ЕСПБ): Увод у професију педагога, и Филозофија васпитања и образовања; затим по један изборни блок: Изборни блок 3 (4 ЕСПБ): Енглески језик, Француски језик и Немачки језик; Изборни блок 4 (5 ЕСПБ): Национална историја педагогије, Етика у образовању, Српски језик и функционална писменост, Медијска писменост у дигиталном добу; Изборни блок 5 ( 4 ЕСПБ): Енглески језик, Француски језик и Немачки језик; Изборни блок 6 ( 5 ЕСПБ): Педагошко академско писање, Образовање и социјална селекција, Заштита менталног здравља, Социологија омладине; Изборни блок 7 ( 4 ЕСПБ): Енглески језик, Француски језик и Немачки језик; Изборни блок 8 (5 ЕСПБ): Дечја игра и стваралаштво, Докимологија, Основи социјалне педагогије, Социологија наставника; Изборни блок 9 ( 6 ЕСПБ): Високошколска педагогија, Педагошка превенција поремећаја у понашању, Интеркултурално васпитање, Педагошко академско писање; Изборни блок 10 (5 ЕСПБ): Инклузивно образовање, Школски менанџмент, Образовање за треће доба, Одрастање у дигиталном окружењу; Изборни блок 11 (5 ЕСПБ): Интерактивне методе, Андрагошка дидактика, Алтернативне школе, Настава грађанског васпитања. У најновијем наставном плану обогаћени су садржаји изборног подручја знатно већим бројем изборних предмета, што заиста представља адекватну могућност за профилисање студија према афинитетима студената. У структури студијског програма заступљено је око $15 \%$ академско-општеобразовних, око 20\% теоријско-методолошких, око $35 \%$ научно-стручних и око $30 \%$ стручно-апликативних предемта у односу на укупан број кредита свих понуђених наставних предмета. Када је реч о стручној пракси, такође се може рећи да је она заступљена на адекватнији начин, присутна је још од друге године студија, што до сада није било присутно ни у једном од претходних наставних планова.

Сврха најновијег програма ОАС педагогије је образовање и оспособљавање студената за успешно обављање позива стручног сарадника - педагога y: предшколским установама, основним и средњим школама, установама социјалне и здравствене заштите, установама у области културе и другим службама јавног сектора, невладиним организацијама и секторима за људске ресурсе, као и другим институционалним и ванинституционалним делатностима васпитања и образовања. Основне академске студије педагогије усмерене су на стицање и јачање друштвено оправданих, корисних и професионално значајних компетенција за: теоријско и практично идентификовање, проучавање 
и истраживање васпитно-образовних проблема; активно учешће у планирању, реализацији и анализи васпитно-образовног рада; реално сагледавање и активан однос према ресурсима и потенцијалима педагошке теорије и праксе (поступака, облика и метода рада); практичан рад и стваралаштво у домену педагошке професије; унапређивање, иновирање и усавршавање педагошког рада у савременом друштву; континуирано учење и професионално усавршавање. Сврха студијског програма усмерена је и на развој комуникационих и социјалних компетенција, организационих вештина, способности конструктивног приступа педагошкој теорији и пракси као и способностима које су услов за успешно обављање непосредне практичне делатности: познавање етичких и моралних норми професије, интеркултуралност и мултикултуралност, компетенције саветодавног рада, дидактичке и методичке компетенције, лидерске компетенције, и слично. Циљ програма је у новој акредитацији доста разрађен, те општи циљ јесте постизање кључних компетенција и академских вештина неопходних за успешно обављање професије педагога: овладавања релевантним теоријским концептима, принципима и законитостима; планирања, реализовања и унапређивања васпитно-образовног процеса; самосталног практичног рада у свим врстама образовних установа и установама социјалне заштите у својству стручног сарадника; као и самосталног и стваралачког истраживања васпитно-образовних проблема. Из општег циља студијског програма произилази низ посебних циљева: овладавање релевантним теоријским концептима, принципима и законитостима васпитно-образовног процеса; упознавање актуелних трендова, алата и метода педагошког рада; разумевање, критичко промишљање и примена релевантних педагошких знања; развијање креативних способности и специфичних практичних вештина потребних за успешно обављање професије; схватање комплексности функционисања образовних установа као дела система васпитања и међузависности социјалних интеракција у њему; оспособљавање за планирање образовног рада заснованог на индивидуалним и групним одликама васпитаника, специфичностима васпитно-образовног контекста, шире друштвене средине и општим циљевима савременог васпитања и образовања; разумевање улоге педагога у васпитно-образовном процесу и развијање спремности за стицање компетенција неопходних за њихово успешно остваривање; оспособљавање за идентификацију, разумевање и решавање изазова и тешкоћа у васпитно-образовном раду, односно осмишљавање, планирање и реализација самосталног практичног рада у свим врстама образовних установа (предшколске установе, основне и средње школе, установе социјалне заштите, установе за образовање одраслих, посебно профилисане образовне институције, и др.); оспособљавање за истраживање и евалуацију васпитно-образовних активности и постигнућа; развијање истраживачког и стваралачког односа према васпитној делатности и сопственом раду; схватање проблема непосредне практичне делатности, њихово критичко промишљање и проналажење креативних начина за њихово решавање; развијање професионалног идентитета и оспособљавање за професионално усавршавање, иновирање и унапређивање рада; овладавање савременом технологијом као видом 
подршке васпитно-образовног процеса; оспособљавање за конструктивну комуникацију, сараднички рад и подршку свим актерима образовно-васпитног процеса; прецизно конципирање, анализирање и поређење истраживачких налаза, компетентно презентовање и активна примена у раду. Исходи учења се ослањају на дескрипторе квалификација за овај ниво образовања у научној области педагошких и андрагошких наука, као и на одговарајућем европском нивоу квалификација. Савладавањем студијског програма студент стиче опште и предметно-специфичне компетенције квалитетног обављања педагошке делатности које су усаглашене са одговарајућим нивоима Националног оквира квалификација у Републици Србији. У оквиру општих компетенција очекује се да ће студенти бити оспособљени да: примењују систематизована академска знања из педагошке теорије и праксе; критички и самокритички просуђују и вреднују појаве и процесе васпитања и образовања; анализирају, евалуирају и усавршавају професионалну делатност користећи савремена научна знања, примере добре праксе и резултате вредновања и самовредновања; развијају комуникационе компетенције и сарадничке односе са ужим и ширим васпитно-образовним и социјалним контекстом; учествују у тимском раду и другим кооперативним облицима рада, подстичу и развијају квалитетне интеракције међу учесницима васпитно-образовног процеса; испољавају сензибилност за етичке, мултиетичке и интеркултуралне проблеме; овладају методама, техникама и процесима истраживачког рада, прецизно конципирају налазе својих и других истраживања и систематски презентују утврђене резултате; усаглашавају васпитно-образовни рад са актуелним иновацијама у педагошкој делатности; изграђују професионалну етичност педагошког позива. Предметно-специфичне компетенције омогућавају студентима да: тумаче васпитање и образовање са аспекта савремених концепција образовања и критички сагледавају њихово значење у пракси; прате и примењују савремена научна сазнања и новине из области педагогије; демонстрирају иновативност, научни и професионални интегритет и посвећеност развијању нових идеја и унапређивању васпитно-образовног рада; поседују дидактичко-методичка знања и компетенције неопходне за успешно обављање позива стручног сарадника - педагога; користе разноврсне методе, технике, облике рада и доступна наставна средства у циљу обезбеђивања квалитета рада; планирају и реализују васпитно-образовни рад користећи разноврсне методичке поступке усклађене са циљевима, исходима и стандардима постигнућа, специфичностима васпитно-образовног контекста, узрасним и индивидуалним капацитетима и потребама васпитаника; примењују информационо-комуникационе технологије за унапређивање васпитања, образовања, наставе и учења; дијагностификују, истражују и решавају конкретне проблеме у васпитно-образовној пракси употребом научних метода и поступака; развијају и примењују напредне и специјализоване вештине и технике решавања кључних проблема васпитно-образовног рада и истраживања; креирају, анализирају и спроводе истраживања значајна за унапређивање педагошке теорије и праксе; континуирано прате и вреднују квалитет и ефективност васпитно-образовне праксе користећи различите врсте и технике 
евалуације; развијају позитиван активистички однос према континуираном целоживотном учењу, личном и професионалном развоју и усавршавању.

Прегледом циљева и исхода студијског програма, можемо констатовати да постоји потпуна усаглашеност циљева и садржаја студијских програма и исхода учења. Нови програм је високо фокусиран на развијање вештина критичког мишљења, креативности, иновативности, интеркултуралности, самосталности и тимског рада, као и лидерских компетенција. Исходи учења усаглашени су са очекиваним компетенцијама студената на бази дескриптора квалификација за овај ниво образовања у научној области педагошких и андрагошких наука, као и на одговарајућем европском нивоу квалификација. Нови програм се високо издваја по јасније дефинисаним стандардима што говори о квалитету програма који је сада на много вишем нивоу, што је плод труда и организације наставног особља на Департману за педагогију Филозофског факултета у Нишу.

\section{Закључак}

У раду је анализирано шест студијских програма Департмана за педагогију од његовог оснивања до ове, 2021. године. Најпре су то били програми 2000. године, 2004. и 2006. године, а затим 2008. године први акредитовани програм у оквиру Болоњске реформе високог образовања, затим следећи 2014. године, и последњи је из ове, 2021. године, када је успешно акредитован најновији студијски програм на Департману за педагогију.

Анализа је показала недвосмислен напредак у развоју програма од оснивања Департмана до данас. У првом студијском програму из 2000. године били су присутни двосеместрални предмети, и чак један четворосеместрални предмет (Општа педагогија), а изборни предмети су били предвићени само на трећој и четвртој години студија, они су такође били двосеместрални. Због одређених недостатака овог програма, сачињен је нови студијски програм, који је усвојен 2004. године, а који се према својој структури разликовао од претходног у односу на број изборних блокова, као и према другачијој заступљености педагошких дисциплина. Уместо искључиво двосеместралних предмета, заступљени су једносеместрални предмети у оквиру изборних предмета. Значајан недостатак овог програма из 2004. године односио се на недовољно праксе која је била заступљена у само седмом семестру, што заиста није омогућавало адекватну практичну оспособљеност будућих педагога. Нови студијски програм усвојен је већ 2006. године, са тенденцијом да се полако започне припрема за прихватање Болоњског процеса, јер су у овом наставном плану присутни ЕСПБ бодови. Нови студијски програм акредитован је 2008. године и то је био први студијски програм који је акредитован према стандардима који су били дефинисани у оквиру Болоњског процеса. Следећи студијски програм акредитован је 2014. године, и имао је повећан број часова стручне праксе у трећој и четвртој години, што је и те како значајно за професионалне компетенције студената педагогије. Најновији студијски програм, успешно је акредито- 
ван ове, 2021. године, и школске 2021/2022. године уписује се прва генерација студената педагогије према овом програму. Сада су присутни нови предмети, што указује на присуство адекватнијих потенцијала за развој Департмана и студијског програма. Стручна пракса је сада заступљена на адекватнији начин, присутна је још од друге године студија, што до сада није било присутно ни у једном од претходних наставних планова.

Сврха студијског програма, дефинисана стандардом, јесте да образује студенте за радно место сарадника у предшколским установама, основним и средњим школама, установама социјалне и здравствене заштите, установама у области културе и другим службама јавног сектора и невладиним организацијама. Прегледом циљева и исхода студијског програма, можемо констатовати да постоји потпуна усаглашеност циљева и садржаја студијских програма и исхода учења. Нови програм је високо фокусиран на развијање вештина критичког мишљења, креативности, иновативности, интеркултуралности, самосталности и тимског рада, као и лидерских компетенција.

Континуиране измене циљева и исхода, допуне и креирање нових предмета на студијском програму ОАС педагогије резултат су сталног критичког преиспитивања актуелног програма, многобројних анализа и као израз тежње да се достигне највиши ниво квалитета студијског програма и компетенција дипломираних студената. Наравно, увек ће постојати простор у коме се сваки студијски програм може даље унапређивати и мењати у складу са динамичним друштвом у коме живимо.

\title{
Литература
}

Акредитације студијског програма основних академских студија педагогије (2008, 2014. и 2021) - публикације установе Филозофски факултет у Нишу.

Програми ОАС педагогије од 2000. до 2021 - публикације установе Филозофски факултет у Нишу (делимично доступне на сајту Факултета: https://www.filfak. ni.ac.rs/studije/osnovne/pedagogija)

Закон о високом образовању (2005). Службени гласник РС, бр. 76.

\section{STUDY PROGRAMS OF BASIC ACADEMIC STUDIES OF PEDAGOGY AT THE FACULTY OF PHILOSOPHY IN NIŠ FROM 2000 TO 2021}

\author{
Marina Matejević, Marija Đorđević
}

University of Nis, Faculty of Philosophy, Department of Pedagogy

Abstract: The paper analyzes six study programs of the Department of Pedagogy from 
its establishment until this year, 2021. The technique of content analysis of available program documents was used. The basic units of analysis were: study program (within it: subjects, electives, accreditation, ECTS, professional practice), purpose, goal and outcomes of the program. The results of the analysis show unequivocal progress in the development of the program since the establishment of the Department until today. In each new program, new subjects were added in accordance with the needs and development of the education system and the social community, which was conditioned by the presence of more adequate potentials at the Department of Pedagogy. There are more and more elective modules and subjects in the programs, and professional practice is represented in an increasingly adequate way. Continuous additions to goals and outcomes, and the creation of new subjects, are the result of constant critical review of the current program, numerous analyzes and the expression of aspirations to reach the highest level of study program quality and competencies of graduate students of pedagogy. Of course, there will always be a space in which each study program can be further improved and changed in accordance with the dynamic society in which we live.

Keywords: Department of pedagogy, OAS, pedagogy, study program.

\section{Цитирање чланка:}

Матејевић, М. и Ђорђевић, М. (2021). Студијски програми основних академских студија педагогије на Филозофском факултету у Нишу од 2000. до 2021. године. Годишњак за педагогију, 6(2), 7-21. 